\title{
Learning Histories and
} Curriculum Innovation in Vocational Education

\section{and Training}

\section{The Case of a Dutch Community College}

\author{
Danny Wildemeersch \\ Katholieke Universiteit Leuven, Belgium \\ Henk Ritzen \\ Edith Stein Institute of Higher Education, Hengelo, Netherlands
}

\begin{abstract}
The article describes and analyzes a case of action research aimed at stimulating a process of curriculum innovation in three departments of a community college in the Netherlands. The project was expected to contribute to the solution of a variety of problems in the institution such as unmotivated teachers and learners, drop out of students, inadequate teaching methods, etc. The Learning History Methodology (LHM) was successfully applied. The article presents the goals and the process of the research, the commitments of the actors involved, the innovation that came about, the transformative learning process of the participants, and the strengths and weaknesses of the research collaboration. The research has confirmed that the "Learning History" can be an excellent action research approach in cases where change and innovation are considered necessary.
\end{abstract}

Keywords: storytelling in organizations; action research; vocational education and training

$\mathrm{I}^{\mathrm{n}}$ $\mathrm{n}$ this article, we present the methodology and the findings of an action research project conducted between 2000 and 2002 in the context of a project of curriculum innovation in a community college in the Netherlands. Community Colleges (Regionale Opleidingencentra) are recent constructions established by law in the

\footnotetext{
Authors' Note: The article has been presented at the Conference "Workplace Learning From the Learner's Perspective." The abstract was included in the proceedings. Wildemeersch, D. \& Ritzen, H. (2004). Learning Histories on Curriculum Innovation in Vocational Education and Training. In K. Illeris (Ed.). Proceedings of the Conference "Workplace Learning from the Learner's Perspective," Copenhagen. Retreived November 25-27, from http://wl-conference2004.1ld.dk. Correspondence concerning this article should be addressed to Danny Wildemeersch, PhD, Full Professor of Social and Intercultural Pedagogy, Katholieke Universiteit Leuven, Belgium and Head of the Centre for the Research on Lifelong Learning and Participation, Department of Education, Vesaliusstraat 2 B-3000 Leuven, Belgium; e-mail: danny.wildemeersch@ped.kuleuven.be.
} 
midst of the 1990s in the Netherlands. These colleges integrate and coordinate all provisions of vocational education and training and adult basic education in a particular region. Four different levels are distinguished, ranging from basic education to higher vocational education and training. In the whole of the Netherlands (16 million inhabitants), more than 50 community colleges have been established. Each college enrols between 10,000 and 20,000 students. The merging of all preexisting schools and programmes into one big institution per region generated a lot of management concerns. In the first stage, priority was given to technical, administrative and financial aspects of the innovation, and the pedagogical dimension was somewhat neglected. A consequence was that quite a few of these institutions struggled with a variety of problems, including a lack of motivation both of practitioners and learners, and dropping out of learners.

Some colleges tried to solve these problems and engaged into actions to improve the teaching and learning conditions. One of these institutions was the Community College East Netherlands (currently named the ROC-van-Twente) in the province of Twente, close to the German border. In this institution, a process of curriculum innovation was started in 2000 in three different departments. It lasted 2.5 years. The objective was to make the teaching and learning process more relevant for the different stakeholders involved: the students, the teachers, the management. Different project-related and work-related education and training activities were initiated, aimed both at strengthening the links between the school and the world of work and renewing the content of the curriculum.

This innovation process was accompanied by an action research project called "Meaningful Learning Trajectories." The education department of the University of Nijmegen ${ }^{1}$ guided this research and introduced the learning history method as a combined action and reflection process in the community college. The inspiration for this methodology came from Kleiner and Roth (1996) who describe their approach as a way to stimulate organizational learning through the collective recollection and interpretation of relevant events and processes that have taken place in an organization: "A learning history is a document that tells an organization its own story" (Roth \& Kleiner, 1998, p. 43). Or, in the words of Bradbury and Mainemelis (2001), it is "designed to allow recognition of what is taken for granted and, based on ensuing conversations from multiple perspectives, to facilitate the dialogical generation of a new future" (p. 340).

With the help of this methodology, researchers collect various kinds of information about the experiences of the participants related to the change process: individual and collective narratives, evaluations, hopes and fears, learning experiences, and so on. Research methods include interviews, observations, and document analysis. The research team interprets these data with the help of a two-column format—a narrative column and an interpretive column. This interpretation results into a document that is then presented to the community where the innovation process takes place. It is hoped that through the creation and presentation of this "interactive text" (Bradbury \& Mainemelis, 2001), a reflective process is initiated, triggering a better understanding of the conditions in which one works and resulting in improvements of the practice at stake. 
With the help of students of the Nijmegen University, two learning history documents were developed in 2000-2001 and in 2001-2002, related to two of the three curriculum innovation practices. Below, we first present the context of the innovation process, followed by the main findings of the research. Next, the research process and the results are evaluated critically from a methodological point of view. Some of the weaknesses, especially with regard to the involvement of students in the research process, are considered. A postfactum student evaluation (Ronda, 2003) has brought some of the weaknesses to the fore. These observations were also helpful in validating the action research findings as part of broader $\mathrm{PhD}$ research in which the coordinator of the innovative action in the community college was engaged during and after this project (Ritzen, 2004).

\section{Innovation Practices and Evaluations}

The innovation process was originally initiated by the board of governors of the Community College as an attempt to improve the educational practices of the college, especially at the basic levels. Three departments of the college engaged in a 2 -year process of innovation. The ambition was to replace the traditional "transfer of knowledge and skills approaches" with more experiential, project, and problem-based learning activities. An important objective of the innovation process was also to create a better fit between the world of the vocational school and the world of work. Students and staff had experienced the school too much as an isolated island, disconnected from the world of labour. In the innovation process, the levels one and two of the learning trajectories in Community Colleges were addressed. These levels provide basic vocational education and training. Students who have successfully passed the primary and secondary level can move further to Level 3, which offers a high school degree. The top level is Level 4, which offers a college degree (professional bachelor). Priority was given to Levels 1 and 2 because various problems had been experienced with the students there, such as drop out and lack of motivation. The ages of the students in the two basic levels range between 16 and 20. The three departments prepare students for jobs in three different professional fields: care (e.g., basic nursing), the information and communication technology sector (e.g., computer and network installation maintenance), and commerce (e.g., shop assistants).

This innovation process resulted in complex multilevel transformations within the institute that affected the entire teaching and learning process in which staff and students were involved. All partners in the innovation process engaged in a joint action research programme that, in each of the three departments, consisted of the following five phases: problem identification, exploration, general plan, improvement actions, and educational results. In the table below, we summarize the main elements of the innovation practices in the three different departments (Table 1). 
Table 1

Overview of Innovation Practices in Three Departments

\begin{tabular}{|c|c|c|c|}
\hline Department Phase & CARE & ICT & COMMERCE \\
\hline $\begin{array}{l}\text { Problem } \\
\quad \text { identification }\end{array}$ & $\begin{array}{l}\text { Teaching and learning } \\
\text { o Too theoretical } \\
\text { o Traditional teaching } \\
\text { o Too numerous classes } \\
\text { o No incentives for active } \\
\text { participation } \\
\text { o No individualized } \\
\text { approach } \\
\text { Pedagogical relationship } \\
\text { o Lack of competences to } \\
\text { motivate students } \\
\text { o Teachers want more } \\
\text { interaction with } \\
\text { students } \\
\text { Lack of practical training } \\
\text { Mentoring not well } \\
\text { integrated into the } \\
\text { teaching/learning } \\
\text { process }\end{array}$ & $\begin{array}{l}\text { Frictions concerning the } \\
\text { composition of the staff } \\
\text { Frictions concerning the } \\
\text { quality of the } \\
\text { teaching/learning } \\
\text { process } \\
\text { Frictions about the mater- } \\
\text { ial conditions }\end{array}$ & $\begin{array}{l}\text { Discomfort about the } \\
\text { collective organization } \\
\text { of the curriculum (year } \\
\text { groups) } \\
\text { o Lack of discipline } \\
\text { o Content not motivating } \\
\text { o No practice link } \\
\text { o No possibility of } \\
\text { independent learning } \\
\text { o Inadequate classrooms } \\
\text { o Too numerous classes } \\
\text { Problems concerning the } \\
\text { follow-up of the } \\
\text { students } \\
\text { o Lack of coaching skills } \\
\text { o Dysfunctional } \\
\text { registration system } \\
\text { o Inadequate follow-up } \\
\text { system of students } \\
\text { Organizational problems } \\
\text { o High drop-out rate } \\
\text { o Inadequate } \\
\text { infrastructure }\end{array}$ \\
\hline Exploration & $\begin{array}{l}\text { Experiences of students } \\
\text { o Students don't feel at } \\
\text { home very well } \\
\text { o Lack of interest among } \\
\text { teachers for students } \\
\text { o Negative appreciation } \\
\text { of teaching } \\
\text { o School and schedules } \\
\text { are chaotic }\end{array}$ & $\begin{array}{l}\text { Experiences of students } \\
\text { o Feelings of alienation } \\
\text { o Not familiar with teach- } \\
\text { ers } \\
\text { o Negative appreciation } \\
\text { of teaching } \\
\text { o School and schedules } \\
\text { are chaotic }\end{array}$ & $\begin{array}{l}\text { Experiences of students } \\
\text { o Students feel at home } \\
\text { o Lack of interest among } \\
\text { teachers for students } \\
\text { o Negative appreciation } \\
\text { of teaching } \\
\text { o School and schedules } \\
\text { are chaotic }\end{array}$ \\
\hline General plan & $\begin{array}{l}\text { Improvement plans } \\
\text { o Individual intake } \\
\text { o Common basic year } \\
\text { o Max. } 16 \text { students per } \\
\text { class; supported by } 2 \\
\text { mentors } \\
\text { o School-year: } 4 \text { periods } \\
\text { of } 10 \text { weeks } \\
\text { o From second period } \\
\text { onwards: every } 2 \text { weeks } \\
1 \text { week of vocational } \\
\text { practice }\end{array}$ & $\begin{array}{l}\text { Improvement plans } \\
\text { o Individual intake } \\
\text { o Vocational practice as a } \\
\text { point of departure for } \\
\text { the learning process; } \\
\text { alternating theory and } \\
\text { professional practice } \\
\text { o ICT-practice: project } \\
\text { based learning } \\
\text { o Competence based cur- } \\
\text { riculum } \\
\text { o Students act as indepen- } \\
\text { dent learners }\end{array}$ & $\begin{array}{l}\text { Improvement plans } \\
\text { o Individual intake } \\
\text { o Students of all levels } \\
\text { participate in study } \\
\text { groups and have collec- } \\
\text { tive responsibility for } \\
\text { their progress } \\
\text { o School-year: } 4 \text { periods } \\
\text { of } 10 \text { weeks } \\
\text { o Stimulation towards } \\
\text { independent learning } \\
\text { o A "document centre" is } \\
\text { developed including an }\end{array}$ \\
\hline
\end{tabular}


Table 1 (continued)

\begin{tabular}{|c|c|c|c|}
\hline Department Phase & CARE & ICT & COMMERCE \\
\hline & $\begin{array}{l}\text { o Competence tests are } \\
\text { developed to judge } \\
\text { progress } \\
\text { o A developmental port- } \\
\text { folio is developed } \\
\text { o The students act as } \\
\text { independent learners }\end{array}$ & o Teacher acts as coach & $\begin{array}{l}\text { open learning centre, a } \\
\text { library and a media cen- } \\
\text { tre } \\
\text { o No homework (compe- } \\
\text { tence development at } \\
\text { school) } \\
\text { o Teacher as coach }\end{array}$ \\
\hline $\begin{array}{l}\text { Implementing } \\
\text { improvement }\end{array}$ & $\begin{array}{l}\text { o Careful transfer of } \\
\text { responsibilities to } \\
\text { students } \\
\text { o In-team flexibility } \\
\text { among teachers }\end{array}$ & $\begin{array}{l}\text { o Adequate project con- } \\
\text { tents } \\
\text { o Vocational practice } \\
\text { adapted to practice } \\
\text { trainers } \\
\text { o Adaptation of physical } \\
\text { infrastructure to needs } \\
\text { of project based learn- } \\
\text { ing } \\
\text { o Intensification of } \\
\text { student facilitation }\end{array}$ & $\begin{array}{l}\text { o Integration of coaching } \\
\text { roles of teachers } \\
\text { o Investigation of steering } \\
\text { role of teacher } \\
\text { o Intensification of the } \\
\text { teacher-learner relation- } \\
\text { ship }\end{array}$ \\
\hline Educational results & $\begin{array}{l}\text { o Extensive individual- } \\
\text { ized intake based on } \\
\text { assessment of prior } \\
\text { learning experiences } \\
\text { o Educational concept } \\
\text { "Portfolio Diary" as a } \\
\text { basis for self directed } \\
\text { process } \\
\text { o Competence develop- } \\
\text { ment: vocational and } \\
\text { civil competences } \\
\text { o Mentor-groups of eight } \\
\text { students } \\
\text { o Drop Out Prevention } \\
\text { through registration } \\
\text { system } \\
\text { o Regular capacity testing } \\
\text { o Counselling about } \\
\text { future learning or jobs } \\
\text { o Post-study service }\end{array}$ & $\begin{array}{l}\text { o Extensive individual- } \\
\text { ized intake based on } \\
\text { assessment of prior } \\
\text { learning experiences } \\
\text { o Educational concept: } \\
\text { "Productive learning" } \\
\text { as a basis for a self- } \\
\text { directed process } \\
\text { o Competence develop- } \\
\text { ment: vocational and } \\
\text { civil competences } \\
\text { o Mentor-groups } \\
\text { o Drop Out Prevention } \\
\text { through registration } \\
\text { system } \\
\text { o Exam bureau organizes } \\
\text { the evaluation of pro- } \\
\text { jects and modules } \\
\text { o Counselling about } \\
\text { future learning or jobs } \\
\text { o Post-study service }\end{array}$ & $\begin{array}{l}\text { o Extensive individual- } \\
\text { ized intake based on } \\
\text { assessment of prior } \\
\text { learning experiences } \\
\text { o Educational concept: } \\
\text { "Study Department } \\
\text { Store" as a basis for a } \\
\text { self-directed process } \\
\text { o Competence develop- } \\
\text { ment: vocational and } \\
\text { civic competences } \\
\text { o Individualized coaching } \\
\text { of students in school } \\
\text { and during internship } \\
\text { o Testing via competence } \\
\text { based labour tests } \\
\text { o Counselling about } \\
\text { future learning or jobs } \\
\text { o Post-study service }\end{array}$ \\
\hline
\end{tabular}

The board of governors was fairly precise in defining the roles and responsibilities of the different actors from the very start of the innovation process. This could, however, not prevent ambiguities emerging along the line. At the beginning of the process, the teaching staff expressed insecurity about the objectives and responsibilities related 
to the innovation process. Differences in opinion among the management and the teachers initially influenced the process in a negative way. This was due to a lack of initial clarity of the project. However, once the innovation process really got started, the commitment of most of the management and teaching staff was quite intensive. The members of the staff were continually engaged in a reflective process about teaching and learning. They actively contributed to the development of good practices inspired by new pedagogical ideas. The concern was not only practical but also theoretical. They explored scientific concepts, background material, and research data informing them about the nature of the primary process in which they are involved. This resulted in new teaching and learning frameworks and instruments, as well as new kinds of relationships among teachers and students and among teachers themselves. New forms of self-directed learning, project work, and group work were explored and introduced. The teaching faculty were mostly positive about the innovations. However, the students sometimes experienced difficulty to engage with the new methods. Group work is often confrontational for the members taking part. Sometimes, the necessary skills to manage tensions and conflicts resulting from the group dynamics were not available. Students were not experienced enough to assume responsibility for their own learning process. This not only brought about feelings of insecurity, conflict, and doubt but also contradicted the ambitions of the teaching staff who wanted to stimulate the autonomy of the students.

\section{Learning History: Methodology, Implementation, and Findings}

In combination with the innovation process, a learning history research project was begun with the aim of understanding, interpreting, and supporting the process. Today, we increasingly operate in organizational contexts that are characterized by continuous change and transformation. The conditions in which people function have become fairly insecure and unpredictable and, therefore, require new forms of management and governance. Organizational innovations are often accompanied by actions that invite various actors to engage in a reflective way with objectives, strategies, processes, and outcomes. As a consequence, it is acknowledged that various forms of transformative learning are necessary components of organizational change or innovation. These transformations in practice are typically inspired by research concepts and activities that reflect new approaches and understandings of learning in context. Action research is increasingly recognized as an effective way to stimulate reflectivity within a transforming organization (Reason \& Bradbury, 2002). The notion of Communities of Practice (Wenger, 1998) is documenting the learning dimension of all kinds of communities where people engage in joint enterprises. Also, the notion of "social learning" (Wildemeersch, 2007; Wildemeersch, Jansen, Vandenabeele, \& Jans, 1998) is an attempt to understand collective problem-solving activities as a form of learning. 
The practice of the learning history is a particular way to engage in action research in organizations and to stimulate reflective learning among the actors involved. The approach integrates insights from theories of learning that put a strong emphasis on the combination of action and reflection (Bradbury \& Mainemelis, 2001). It highlights the relevance of storytelling as a powerful means to share knowledge in organizations (Sole \& Wilson, 2002). From this viewpoint,

The recounting of stories aloud in front of a third person, intent on bringing out and stimulating the memory of facts and persons, provided an almost unique opportunity for the re-appropriation of the learning experience matured during the work life, and which had in some cases been forgotten. (Cortese, 2005, p. 110)

The learning history describes the history of a process of change in terms of a learning process.

The learning history methodology (LHM) is a practice-oriented research activity that produces a document presenting multiple and often contradictory experiences and understandings of various actors involved in a joint enterprise. The document is edited both in the participants' own subjective narratives and in the more objectifying words of the external observers (researchers). It reports about particular practices and their effects. Next to the stories of concrete experiences, it presents interpretations of underlying assumptions and reasoning of a variety of people. On a more abstract level, LHM develops an organizational infrastructure to support individual and collective learning. An interactive text is constructed, creating a context for conversation, as well as providing a philosophical and methodological basis for addressing issues of assessment.

In the recent past, we have initiated various learning history research activities. One concerned a curriculum innovation activity in the Nijmegen Business School (Basten, 2000). Another focused on the collaboration in an interdisciplinary research group working on water management in North-West Vietnam (Adams, 2001). LHM was considered to be an appropriate approach in the case of the curriculum innovation initiative in the Dutch Community College in Hengelo (ROC-Oost-Nederland). It provided opportunities for different actors to engage reflectively in the process of change. At the same time, students in a university research seminar had the opportunity to participate in "real" research, as interviewers, interpreters, and coauthors of the learning history document (Ronda, 2003; Wetzels, 2002).

LHM was applied in two of the three departments at the community college: the commerce department and the care department. The commerce department was researched between 2000 and 2001 (Wetzels, 2002); the health care department was investigated between 2001 and 2002 (Ronda, 2003). The organization of the learning history research consisted in both cases of six consecutive steps. In both cases, the entire process lasted 4 months. 
- Step 1-research planning: A discussion between the commissioner of the research (the college) and the research group (the university students and staff) led to mutual agreements concerning objectives, field of research, methods, reports, and feedback. Different roles were identified: the research group, the commissioners, the participants (the two departments in the college with their staff), and the "insiders group" (a steering committee of the community college supervising the whole process).

- Step 2-data collection: Roughly, 20 semistructured interviews per case (learning history) were conducted by pairs of university students belonging to the research group. Students and staff of the community college were interviewed about their (learning) experiences related to the process of innovation. The interview transcriptions were later presented to the interviewees, who were invited to correct or add to them.

- Step 3-identification of recurring themes: From the raw data, basic themes were distilled in the first case (commerce department). These themes formed the base for the organization of the narrative. In the second case the following year (care department), the same themes were used to organize the interpretation of the data. The themes were relation and communication, organizational structure, organizational culture, learning experiences.

- Step 4-editing of the learning history: The varied experiences of the participants in the innovation process were described and analyzed with the help of a two-column format. The right column presented the (subjective) narratives of the college actors and the left column presented the objectifying comments of the outsiders (the research team). This process took place in the research group.

- Step 5-validation of the research findings by the insiders group: The researchers discussed their interpretative "work-in-progress" with the insiders group at the occasion of validation workshops. The learning history findings were compared with other evidence coming from more quantitative research activities. Some irritating formulations were corrected.

- Step 6-Discussion of the learning history document: The learning history was discussed by the staff of the two departments at the occasion of action-oriented workshops. Discussion covered the validity of the findings, what could be learned from the experiences, and how teams in other departments could take advantage of the findings.

As mentioned above, the research findings were organized under four different thematic headings. We now present main observations coming out of the learning history.

\section{Relation and Communication}

The innovation process has thoroughly changed the mutual relations and communication patterns of staff and students. The great authority that teachers would wield in their classrooms has been replaced by joint negotiations about the teaching/ learning process characterized by openness, transparency, and respect. The work of the teachers has consequently become more creative and agreeable, and their enthusiasm is reflected by the students. The shift from traditional classroom-based teaching to 
self-directed and interactive learning has helped to diminish the distance between the teacher as coach and the student. There is space for emotions and personal contact. Thus, through innovation, the role of the teacher as educator has become more interesting. The teacher coaches the student. Yet, at the same time, she or he has to look for balances between professionalism and conviviality. The same tension exists on the level of the learning process where the teacher has to look for the right balance between other directedness and self-directedness. The teaching staff was fairly positive about the communication during the innovation process. Within the team, an open, dialogical kind of communication has been experienced. People have been informed regularly about things that matter. Feedback has been experienced in a task-oriented and not in a person-oriented way. However, the possibilities of taskoriented feedback are still too limited.

\section{Organizational Structure}

The organizational structure has been extended with the addition of a fourth management level that is not formally part of the management architecture of the community college. The middle managers from the fourth level informally give direction to the teams of the vocational training departments that are involved in the innovation process. This new management level has been established because the complex educational changes requires a coaching style directed toward the teachers, vocational trainers, and students in view of finding solutions to the problems experienced during the innovation process for all partners involved. The teams have developed toward selfdirected teams during the course of the innovation process. The team has taken all responsibilities needed to reach the objectives of the innovation process. To a certain extent, the team is responsible for the governance and management of its own tasks and commissions.

The students work together in heterogeneous groups and the lectures are practice oriented. Students prefer this practice orientation. Teachers are concerned about an increased lack of theoretical background and deepening. The students are responsible for their own learning process and are supported by coaches who facilitate their learning and look for solutions to their problems. The general conviction is that students within the commerce and care departments are now better supported; they are being increasingly encouraged to engage in independent learning, according to their teachers, they have become more critical and expressive.

\section{Organizational Culture}

The process of change that has taken place due to the innovation action implies a cultural transformation that is, in principle, hard to achieve, but which came to a good end in this case. The commitment of the teaching staff and their students are critical elements in this transformation process. In the various sections, there is a 
great enthusiasm about the innovation and the possibility to contribute to it. As a result of the group coaching and the alternating group compositions, the students and the teachers get to know each other. However, the commerce department is not critical enough about the degree of openness and the group cohesion in the team. The culture in this department is fairly "closed," whereas openness is an important objective.

\section{Learning Experiences}

The community college management board has learned that a blueprint approach to innovation in this case is neither relevant nor adequate. It has experienced that a major element of the success of the innovation results from the transfer of means and responsibilities to the actors who have to realize the programme. This means that the managers have had to unlearn the practice of taking their employees "by the hand." The directors of the schools (departments) have remained at a distance during the innovation process. The directors were at times not informed about the processes and products of the innovation. This delayed the process. This was experienced sometimes by the actors on the ground level as a lack of commitment on behalf of the directors. The middle managers have delegated a lot of responsibilities to the ground-level actors: the coordinator of the innovation process and the project leaders assigned to the innovation teams. In this way, the coordinators learned to function as middle managers. This resulted into the creation of an additional decision-making level. The teachers have learned a lot from the transition of their role from lecturer to coach. They have learned what the individual coaching of independent and expressive students is about. The coaching strategies of the teachers in the various departments are quite varied. One teacher is mainly concerned about the life-world of the students; another one is rather focussed on the availability of the learning materials; a third one mainly tries to establish a convivial relationship with the students. Teachers learn from each other through the exchange of experiences, through giving and receiving feedback, and through developing new relationships with the students. They have also learned to operate as teams. Joint planning and structured negotiations took place about the content and the organization of the curriculum. On the whole, the teachers have experienced various transformations in their practice.

- Transformation from teacher to coach: New skills and attitudes are needed; more systematic learning is necessary to help them from falling back into to the old patterns.

- Increased practice orientation: The mentoring invites them to pay more attention to the practice relevance of the learning of the students.

- Taking over roles and tasks of the middle managers, in spite of the fact that the teachers do not dispose of clear scripts as this shift is not formally acknowledged by the management of the community college.

- The teachers have learned to work in self-directed teams that are responsible for the results of the programme. 


\section{Major Conclusions of the Learning History}

A first conclusion is that the LHM is an adequate approach for the actors to get engaged in the innovation process and to reflect on their actions. The feedback from the learning history has given them confidence; they have experienced that they are not operating on their own; they have shared experiences, problems, and challenges with each other; and they have learned from each other. The learning history document has created important insights into the different perspectives on quality, as well as on the strengths and limitations of the innovation strategy. The individual actors are also invited to compare their own experiences to the findings in the learning history. The document has also been useful for sharing experiences not only within the departments but also across the departments. Other schools and departments that were not involved in the innovation process have taken advantage of this research.

A second conclusion is that LHM has documented and analyzed the major curriculum transformations that have taken place in the commerce and care departments. These changes necessitate the redesign of educational methods, of support strategies, and of the internship activities directed at the development of professional identities and responsibilities of the students.

A third conclusion relates to the behaviour of students and staff. Students work together better. Students become more responsible. These changes are evaluated positively by the teachers. At the same time, they observe that the self-direction and critical attitude of the students may cause tensions vis-à-vis the teachers. It is not so easy for the teachers to find a good balance between "letting go" and "giving direction." Also, for the student, it is a challenge to manage challenges and limitations in a new way.

The fourth conclusion concerns students' increased responsibilities. They take their learning trajectories more into their own hands. They also critically reflect upon their learning and the support that is given. They have established an open, informal, and confidential relationship with their teachers.

The fifth conclusion concerns the atmosphere among the students. The staff has experienced an improvement of the group climate. Students quarrel less. Yet, the group atmosphere can still be improved. Some students report that within the student community, distinctions are made between the "smart" and the "dumb" and that this creates conflicts. Some of the students feel unsafe within the group.

The sixth conclusion is about the changes in roles and responsibilities of both students and teachers. Students are now more practice oriented; they work together in groups and operate more independently and responsibly. Teachers have become coaches and have taken over some tasks of the middle management. The innovation has brought a redistribution of responsibilities within the faculty. The general opinion now is that there is better pedagogical guidance of the students. In the care department, however, there is some discomfort with the introduction of the "portfolio diary," which structures the individual learning trajectories of the students. A particular problem is that this tends to require additional administrative work from the teaching staff. 
The final conclusion is about the increased responsibility for the learning process. Some students take up these responsibilities well enough. Others, however, have difficulty doing so. The faculty staff wonder whether the students are ready to assume this increased responsibility. In some cases, more intensive coaching may be needed so that the students can indeed experience the value of being responsible for their own learning process.

\section{The Learning History as Part of a Training Programme for Students: Some Critical Comments}

As mentioned before, the learning history method was implemented twice in two consecutive years. In the academic year from 2001 to 2002, the learning history was organized in the commerce department. In the following academic year from 2002 to 2003 , the method was used in the care department. The construction of the learning history documents was to a large extent based on semistructured interviews conducted by university students from the Department of Educational Sciences of the University of Nijmegen. This task was part of a research methodology seminar aimed at familiarizing third- and fourth-year students with qualitative research methods. In this seminar, an in-depth introduction into the LHM was a central activity. Also, here, the lecturers gave up their traditional teaching role and fostered a form of active learning by the students. During this exercise, the lecturers struggled with four major tensions (Ronda, 2003), which may have influenced the quality of the research methodology.

- The tension related to differential understandings of the research methodology. Students who have been trained mainly in quantitative research methodology have difficulty in appropriating the philosophy and the techniques of qualitative approaches, such as LHM. In our case, they had difficulty in understanding the objectives of this methodology. They initially acted as experts who were supposed to assess the successes and failures of the innovation process. LHM, on the contrary, focuses on "interpretations," on the "life-world" of people belonging to particular communities. The goal of this method is to understand how people interpret the conditions in which they live and operate and to then share this understanding with them to increase their reflective capacity. It took quite some time for the seminar participants to gain familiarity with this view on research. Consequently, some (mis)understanding may have initially influenced their attitude as interviewers. We were able to correct this, however, so that this did not overly influence the general direction of the research.

- The tension between self-directedness and the necessity to achieve quality in the research process. In each case, the development of the learning history document took 4 months. This time frame was limited both by the time limitations of the research seminar and by constraints of the larger action research project. This prevented the 
students from developing insights concerning the methodology at their own. It prevented to a large extent self-directed action and learning among students. The lecturers carefully guarded the time frame as they were coresponsible for the wider context in which the research was situated.

- The tension of different expectations of students and teachers about the outcomes of the research. Students were positive about the "real life" character of the research seminar. They were motivated to deliver quality, and they experienced genuine "learning from experience" opportunities. Yet, there were inevitable discrepancies between the expectations of the students and those of the lecturers. The lecturers were more concerned than the students to guarantee quality. However, higher quality was hard to achieve, given the limitations that are nowadays experienced in universities due to budget reductions, decreases in teaching staff, and so on. Higher quality has to be delivered with less means. The tensions of the external context are reflected in the management of the learning process and the responsibilities vis-à-vis the outside world-in this case, to deliver high quality research quality.

- The tension of different institutional expectations concerning the quality of the research. The research was commissioned by an institution external to the university, where the research experiment was organized. A research experiment in the context of a university seminar and "real life" research implicate different quality standards. The university classroom experiment has achieved the desired outcome when the learning has been successful. The "real life" research achieves is of high quality when criteria of good research are met (validity, reliability, transparency, etc.). To a certain extent, these differential quality standards increased pressure on both the learning and the research process and may have influenced the process and the outcomes.

By way of conclusion, it is worth observing that these four tensions, experienced in the context of learning to research in "real-life settings," are tensions that the initiators of the innovation project also encountered in a different way and at different occasions in their attempt to make the educational process more relevant to the students and to the world of labour "out there." Increasing the practical and experiential relevance of a curriculum creates tensions with disciplinary traditions, with the dynamics, rhythms, and values of learning and education, and between differential quality standards. These tensions and paradoxes are probably inevitable. However, it is important to be aware of them and to take them into consideration when one engages in discussions about practice-relevant education and training. This awareness may help us to understand better what one loses and what one gains in trying to construct "meaningful learning trajectories."

\section{Note}

1. The authors of this article wish to express their gratitude to the colleagues Dr. Ben Hövels and Dr. Theo Jansen who contributed strongly to this research. 


\section{References}

Adams, M. (2001). Learning experiences related to an intercultural, interdisciplinary and participatory context. Unpublished master's thesis, Katholieke Universiteit Leuven, Faculty of Psychology and Educational Sciences, Leuven, Belgium.

Basten, F. (2000). Metaforen en verhalen over organisatiewetenschap en onderwijsinnovatie [Metaphors and narratives about organization science and educational innovation]. Unpublished doctoral thesis, Faculty of Social Sciences, Radboud University, Nijmegen, Netherlands.

Bradbury, H., \& Mainemelis, C. (2001). Learning history and organizational praxis. Journal of Management Inquiry, 10, 340-357.

Cortese, C. G. (2005). Learning through teaching. Management Learning, 36(1), 87-117.

Kleiner, A., \& Roth, G. (1996). Field manual for a learning Historian. Boston: Reflection Learning.

Reason, P., \& Bradbury, H. (Eds.). (2002). Handbook of action research: Participatory inquiry and practice. London: Sage.

Ritzen, H. (2004). Zinvolle leerwegen. Actie-onderzoek naar innovatieve leeromgevingen voor ROC-leerlingen van de kwalificatieniveaus 1 en 2 [Meaningful learning trajectories. Action-research on innovative learning environments for Community College students at qualification levels 1 and 2]. Unpublished doctoral thesis, Radboud Universiteit Nijmegen, Nijmegen, Netherlands.

Ronda, H. (2003). Studentactiverend onderwijs: Theorie in praktijk [Student activating education: Theory in practice]. Unpublished master's thesis, Radboud Universiteit, Faculteit Sociale Wetenschappen, Nijmegen, Netherlands.

Roth, G. L., \& Kleiner, A. (1998). Developing organizational memory through learning histories. Organizational Dynamics, 27(2), 43-60.

Sole, D., \& Wilson, D. (2002). Storytelling in organizations: The power and traps of using stories to share knowledge in organizations. Boston: LILA, Harvard Graduate School of Education. Retrieved May 4, 2008, from http://www.providersedge.com/docs/km_articles/Storytelling_in_Organizations.pdf

Wenger, E. (1998). Communities of practice. Cambridge, UK: Cambridge University Press.

Wetzels, S. (2002). Naar zinvolle leerwegen voor laagopgeleide ROC-deelnemers [Towards meaningful learning trajectories for lowly skilled ROC participants]. Unpublished master's thesis, Radboud Universiteit, Faculteit Sociale Wetenschappen, Nijmegen, Netherlands.

Wildemeersch, D. (2007). Social learning revisited: Lessons learned from North and South. In A. Wals \& T. van der Leij, (Eds.), Social learning towards a more sustainable world (pp. 99-116). Wageningen, Netherlands: Wageningen University Press.

Wildemeersch, D., Jansen, T., Vandenabeele, J., \& Jans, M. (1998). Social learning. A new perspective on learning in participatory systems. Studies in Continuing Education, 20, 251-265.

Danny Wildemeersch, $\mathrm{PhD}$, is a full professor of social, intercultural, and comparative pedagogy, Katholieke Universiteit Leuven, Belgium. He is head of the Centre for the Research on Lifelong Learning and Participation.

Henk Ritzen, PhD, is a lecturer on "Educational Arrangements in the Social Context" at the Edith Stein Institute of Higher Education, Hengelo (the Netherlands). He is a coordinator at the "Regionaal Opleidingscentrum van Twente" (Community College of Twente, the Netherlands). 